\title{
The effect of $6 \%$ Hydroxyethyl starch vs. Ringer's lactate on acute kidney injury after renal ischemia in rats ${ }^{1}$
}

\author{
Vera Lucia Fernandes de AzevedoI, Paulo Sergio Santana Santos ${ }^{\mathrm{I}}$, Gildàsio Silveira de Oliveira Jr." , Gabriel Pinheiro Módolo ${ }^{\mathrm{III}}$, \\ Maria Aparecida Custódio Domingues ${ }^{\mathrm{IV}}$, Yara Marcondes Machado Castigliav, Pedro Thadeu Galvão Viannav, Luiz Antonio

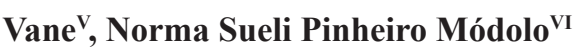

IFellow PhD degree, Postgraduate Program in Anesthesiology, Botucatu Medical School, UNESP, Sao Paulo, Brazil. Acquisition and interpretation of data, involved in experimental procedures, manuscript preparation.

IIAssistant Professor, Department of Anesthesiology, Northwestern University, Feinberg School of Medicine, Chicago, Illinois, USA. Analysis of data, manuscript writing, critical revision.

III Graduate student, Santa Casa Faculty of Medicine of Sao Paulo, Brazil. Acquisition of data, helped with technical procedures.

${ }^{\text {IV }} \mathrm{PhD}$, Assistant Professor, Department of Pathology, Botucatu Medical School, UNESP, Sao Paulo Brazil. Histhopatological examinations.

${ }^{v} \mathrm{PhD}$, Full Professor of Anesthesiology, Department of Anesthesiology, Botucatu Medical School, UNESP, Sao Paulo, Brazil. Design of the study, critical revision.

${ }^{\mathrm{V}} \mathrm{PhD}$, Full Professor of Anesthesiology, Department of Anesthesiology, Botucatu Medical School, UNESP, Sao Paulo Brazil. Design of the study, analysis of data, manuscript preparation, supervised all phases of study.

\begin{abstract}
PURPOSE: To compare fluid replacement therapy with Hydroxyethyl starch 6\% (HES) versus Ringer's lactate (RL) in a rodent model of non-septic renal ischemia.

METHODS: Forty male Wistar rats were randomized to receive HES $2 \mathrm{ml}^{\mathrm{kg}} \mathrm{kg}^{-1} \cdot \mathrm{hr}^{-1}$ or RL $5 \mathrm{ml} . \mathrm{kg}^{-1} \cdot \mathrm{hr}^{-1}$ that underwent $30 \mathrm{minutes}$ of renal ischemia followed by reperfusion. Twelve hours after kidney ischemia, the kidneys were evaluated for histological changes. Serum NGAL levels were obtained at different times of the experimental protocol.

RESULTS: Rodents in the HES group had a median (IQR) grade of renal injury 3 (3 to 5) compared to 2 (2 to 4 ) in the RL group $(\mathrm{p}=0.03)$. NGAL levels were not associated with the severity of kidney injury.

CONCLUSION: Hydroxyethyl starch administration caused more kidney injury than Ringer's lactate in a non-infectious model of renal hypoperfusion.
\end{abstract}

Key words: Acute Kidney Injury. Fluid Therapy. Colloids. Hetastarch. Rats. 


\section{Introduction}

Acute renal failure affects up to $5 \%$ of hospitalized patients and its prevalence is expected to increase in the coming years ${ }^{1}$.Besides causing an increase in mortality, the development of acute renal failure in hospitalized patients can also lead to a greater length of hospitalization and increase in health care costs $^{2}$.Ischemic kidney damage is one of the most important pathophysiologic mechanisms of acute renal failure ${ }^{3}$. Fluid replacement therapy is the cornerstone to prevent and treat acute kidney failure in hypoperfusion states ${ }^{4}$.

Crystalloid and colloid infusions are commonly utilized to treat hypoperfusion states. Despite the poor evidence to justify its use, colloid solutions are frequently administered by clinical practitioners in order to obtain a faster optimization of the intravascular circulatory volume ${ }^{5,6}$. In contrast, colloid infusions have been shown to be detrimental to kidney function when compared to crystalloid infusions in a rodent model of sepsis ${ }^{7}$. Currently, it is unknown if colloid administration is also detrimental to the kidneys in non- infectious states of renal hypoperfusion.

The primary objective of the current investigation was to evaluate the effect of $6 \%$ Hydroxyethyl starch versus Ringer's lactate replacement therapy on the degree of acute kidney injury in a non- infectious rodent model of renal ischemia. We hypothesized that rodents receiving a crystalloid infusion would have less acute structural kidney damage than rodents receiving a colloid infusion.

\section{Methods}

After approval of the Committee for Ethical conduct of animal research at Botucatu Medical School, Sao Paulo, Brazil, 40 male Wistar rats, weighting more than $350 \mathrm{~g}$ were included in the study. Animals were cared for according to the guidelines of the US national institute of health and the Brazilian National Institute of health Standards.

Animals fasted for twelve hours prior to the experiment. After being weighed, they were randomized using a computer generated table of random number and a 1:1 allocation into two experimental groups: Group 1 (Ringer lactate + renal ischemia, $\mathrm{n}=20)$, Group 2 (6\% Hydroxyethyl starch + renal ischemia, $\mathrm{n}=20)$. The animals were anesthetized using isoflurane. After tracheal intubation they were connected to a ventilator (683 Rodent Ventilator, Harvard Apparatus Inc, USA) and were ventilated utilizing a $100 \%$ fraction of inspired oxygen , a respiratory rate set at $60-70$ breaths per minute and tidal volume of 5-10 ml. $\mathrm{kg}^{-1}$. The respiratory rate was adjusted to maintain normocapnia. The animals were kept in a termal cushion in order to prevent hypothermia. Heart rate, invasive blood pressure and rectal temperature were continuously monitored in all studied animals. The right cervical and median abdominal area were then infiltrated with $2 \mathrm{mg} / \mathrm{kg}$ of bupivacaine $0.125 \%$. A right cervical incision was performed and the right jugular vein and the right carotid artery were cannulated under direct vision using a $24 \mathrm{G}$ angiocath. The right jugular vein was cannulated to infuse the study solution and the right carotid artery to establish an invasive blood pressure monitoring and to obtain blood samples. After establishment of the central venous access, the fluid replacement solution was started in both groups using an infusion pump( ANNE, Abbott Laboratories, Abbott Park, USA) using 5ml.kg ${ }^{-1} \mathrm{hr}^{-1}$ Ringer' lactate (HalexIstar, Sao Paulo, Brazil ) for Group 1 and $2 \mathrm{ml} \cdot \mathrm{kg}^{-1} \cdot \mathrm{hr}^{-1}$ of $6 \%$ Hydroxyethyl starch (Voluven, Hospira, Lake Forest, USA) for Group 2. A laparotomy using a median incision was then performed, followed by a right nephrectomy and clamping of the left renal artery for 30 minutes. The arterial clamp was then removed and reperfusion of the kidney was observed for 30 minutes. This model of renal ischemia has been previously demonstrated and used by our group $^{8,9}$. The abdominal and the cervical incisions were then sutured. The anesthetic agent was then stopped and the animals were extubated.

Twelve hours after the initial experiment, the animals were re-anesthetized using isoflurane, the abdominal incision sutures were opened and a left nephrectomy performed. Aspiration of intracardiac blood was performed followed by an intracardiac injection of sodium thiopenthal in order to sacrifice the animals.

Blood samples were obtained to measure serum levels of Neutrophil gelatinase-associated lipocalin (NGAL) at baseline, 30 minutes after renal ischemia, 30 minutes after renal reperfusion and 12 hours after renal ischemia. At each time, $1.5 \mathrm{~mL}$ of blood were obtained followed by infusion of $3 \mathrm{ml}$ bolus of ringer lactate for group 1 and $1.5 \mathrm{~mL}$ of $6 \%$ Hydroxyethyl starch for group 2 .

The kidneys were removed and were preserved using a Duboscq-Brasil solution for 24 hours followed by a solution containing 80\% alcohol, picric acid, formalin and acetic acid. The Duboscq-Brasil solution was utilized to better preserve the kidney structure and to increase the accuracy of the histological analysis. The hematoxilin-eosin marker was used to highlight the structures. The histological slides were then prepared using paraffin. The histological slides were evaluated by a single attending pathologist (MRD) blinded to the study group allocation. The kidney injury was classified according to the percentage of tubular necrosis using the classification previously described by Park et al. ${ }^{10}$ (Table 1). 
The effect of $6 \%$ Hydroxyethyl starch vs. Ringer's lactate on acute kidney injury after renal ischemia in rats

TABLE 1 - Scores of histological injury.

\begin{tabular}{ccc}
\hline Grade & Type & Tubular necrosis(\%) \\
\hline 0 & No lesion & 0 \\
1 & Mild & $<10 \%$ \\
2 & Moderate & 10 to $25 \%$ \\
3 & Moderate to severe & 25 to $50 \%$ \\
4 & Severe & 50 to $75 \%$ \\
5 & Very severe & $>75 \%$ \\
\hline
\end{tabular}

Adapted from Park et al. ${ }^{10}$

The study primary outcome was the degree of kidney injury according to Park's classification. A secondary objective of the study was to evaluate the association between the serum levels of NGAL and the degree of histological kidney injury.

\section{Statistical analysis}

A power analysis determined that 18 rodents per group would be required in order to achieve $80 \%$ power to detect an alternative hypothesis of a one grade of kidney lesion difference in the Hydroxyethyl starch group (median Park classification of 3) compared to the Ringer's lactate group (median Park classification of 2), using one lesion grade as a standard deviation and a two sided non parametric Mann-Whitey U test. The sample size calculation was made using PASS version 11.0.6 release date May 30, 2011 (NCSS, LLC, Kaysville, UT).

The Shapiro-Wilk and Kolmogorov-Smirnov tests were used to test the hypothesis of normal distribution. Normally distributed interval data are reported as mean (SD) and were evaluated using independent $\mathrm{t}$ - test for unequal variance. Nonnormally distributed interval and ordinal data are reported as median (range or Interquartile range (IRQ)) and compared among groups using the Mann Whitney $U$ test. Univariate association between NGAL levels and severity of kidney injury was evaluated using Kruskal Wallis H test. All reported p values are two-tailed. A $\mathrm{p}<0.05$ was used to reject the null hypothesis. Statistical analysis was performed using STATA version 11 (College Station, Texas, USA).

\section{Results}

There was no significant difference in animals' weight between the Hydroxyethyl starch group, mean (SD) of $455 \mathrm{~g} \pm 44$ and the Ringer's lactate group, mean (SD) of $455 \mathrm{~g} \pm 44(\mathrm{p}=0.93)$. Temperature and hemodynamic characteristics were also similar between the study groups at the different times of the experimental protocol (Table 2).
TABLE 2 - Hemodynamic and temperature characteristics of study groups.

\begin{tabular}{cccc}
\hline & $\begin{array}{c}\text { Ringer } \\
\text { Lactate }\end{array}$ & $\begin{array}{c}6 \% \\
\text { Hydroxyethyl } \\
\text { starch }\end{array}$ & p value \\
\hline $\begin{array}{c}\text { MAP before } \\
\text { clamping(mmHg) }\end{array}$ & $109 \pm 17$ & $109 \pm 16$ & 0.95 \\
$\begin{array}{c}\text { MAP 30 minutes after } \\
\text { clamping(mmHg) }\end{array}$ & $112 \pm 18$ & $108 \pm 25$ & 0.59 \\
$\begin{array}{c}\text { MAP 30 minutes after } \\
\text { reperfusion(mmHg) }\end{array}$ & $110 \pm 13$ & $107 \pm 19$ & 0.59 \\
$\begin{array}{c}\text { MAP 12 hours after } \\
\text { clamping(mmHg) }\end{array}$ & $108 \pm 14$ & $106 \pm 16$ & 0.67 \\
$\begin{array}{c}\text { Temperature before } \\
\text { clamping(Celsius degrees) }\end{array}$ & $36.4 \pm 0.8$ & $36.2 \pm 1.9$ & 0.45 \\
$\begin{array}{c}\text { Temperature 30 } \\
\text { minutes after clamping } \\
\text { (Celsius degrees) }\end{array}$ & $36.9 \pm 0.9$ & $36.6 \pm 2.5$ & 0.66 \\
$\begin{array}{c}\text { Temperature 30 minutes } \\
\text { after reperfusion } \\
\text { (Celsius degrees) }\end{array}$ & $37.3 \pm 0.9$ & $37.1 \pm 2.5$ & 0.79 \\
$\begin{array}{c}\text { Temperature 12 } \\
\text { hours after clamping } \\
\text { (Celsius degrees) }\end{array}$ & $37.5 \pm 0.6$ & $36.9 \pm 2.4$ & 0.33 \\
\hline
\end{tabular}

Animals receiving a crystalloid infusion had less renal injury after the ischemic event on the left kidney, median (IQR) grade on Park' classification of 2 (2 to 4 ) compared to animals who received a colloid infusion, median (IQR) grade on Park' classification of 3(3 to 5) ( $\mathrm{p}=0.03$ ) (Figures 1 and 2).

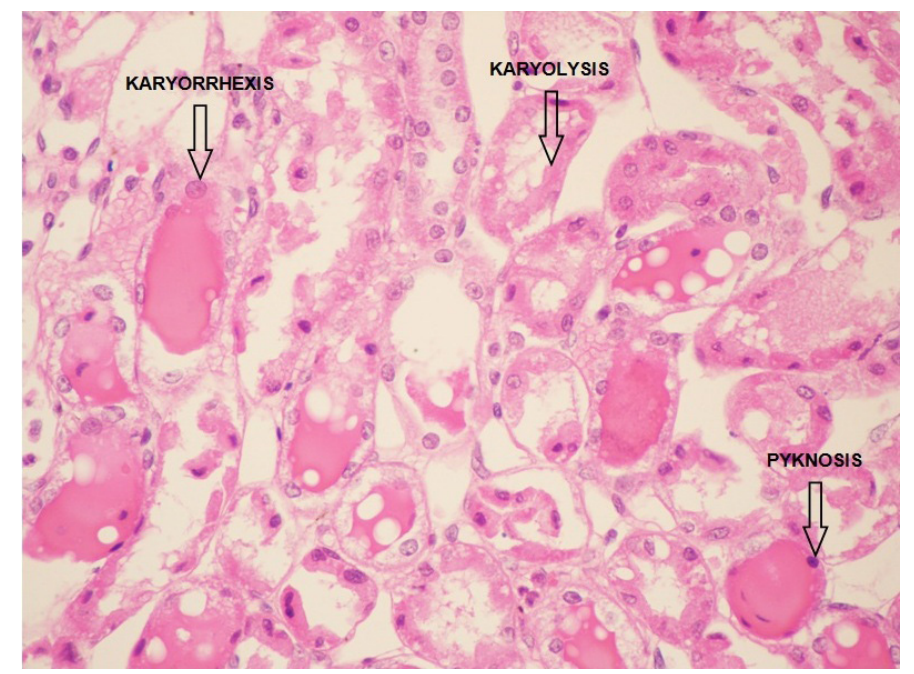

FIGURE 1 - Histological slide demonstrating $10-25 \%$ of renal tubular necrosis in the Ringer's lactate group (Park class 2). Arrows indicate the presence of pinocytosis. (Image is increased by 400x). 


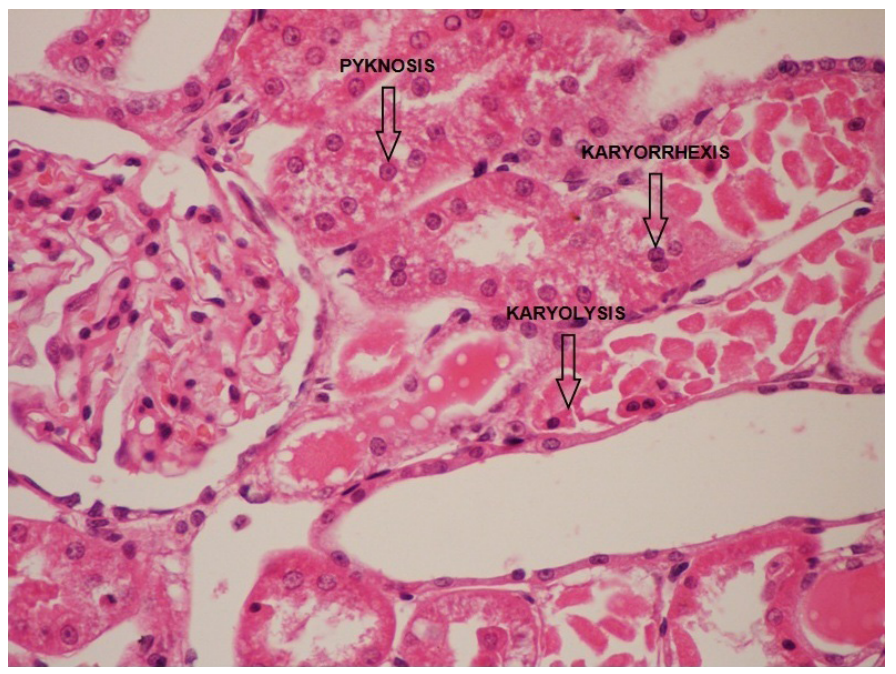

FIGURE 2 - Histological slide demonstrating 25-50\% of renal tubular necrosis in the Hydroxyethyl starch group. Arrows indicate the presence of pinocytosis. (Image is increased by 400x).

The right (non-ischemic) kidney in both study groups had no histological evidence of renal injury, Park classification median (IQR) of 0 (0 to 0$)$.

There was no association between Serum NGAL levels and the severity of kidney injury at the different experimental protocol time points, suggesting a limited role of serum NGAL levels as a biomarker for the severity of acute kidney injury (Table $3)$.

TABLE 3 - NGAL levels by severity of kidney injury.

\begin{tabular}{|c|c|c|c|c|c|c|}
\hline & Park I & Park II & Park III & Park IV & Park V & $\mathrm{p}$ value \\
\hline $\begin{array}{l}\text { NGAL } \\
\text { before } \\
\text { kidney } \\
\text { ischemia }\end{array}$ & $\begin{array}{c}0 \\
\text { ( } 0 \text { to } 4 \text { ) }\end{array}$ & $\begin{array}{c}9.5 \\
\text { (6.5 to } 14)\end{array}$ & $\begin{array}{c}5 \\
\text { (4 to } 27)\end{array}$ & $\begin{array}{c}3 \\
\text { (3 to } 6)\end{array}$ & $\begin{array}{c}4 \\
\text { (3 to } 5 \text { ) }\end{array}$ & 0.29 \\
\hline $\begin{array}{l}\text { NGAL } 30 \\
\text { minutes } \\
\text { after kidney } \\
\text { ischemia }\end{array}$ & $\begin{array}{c}1 \\
\text { (0 to } 2)\end{array}$ & $\begin{array}{c}12.5 \\
\text { (9 to } 16)\end{array}$ & $\begin{array}{c}11 \\
\text { (8 to } 14.5 \text { ) }\end{array}$ & $\begin{array}{c}7.5 \\
\text { (5 to } 14)\end{array}$ & $\begin{array}{c}6 \\
\text { (5 to } 7)\end{array}$ & 0.37 \\
\hline $\begin{array}{l}\text { NGAL } 30 \\
\text { minutes } \\
\text { after kidney } \\
\text { reperfusion }\end{array}$ & $\begin{array}{c}1 \\
\text { (o to } 5 \text { ) }\end{array}$ & $\begin{array}{c}16 \\
(10.5 \text { to } 24)\end{array}$ & $\begin{array}{c}12 \\
(8.5 \text { to } 17.5)\end{array}$ & $\begin{array}{c}10 \\
\text { ( } 4 \text { to } 18 \text { ) }\end{array}$ & $\begin{array}{c}8 \\
\text { (3 to } 9 \text { ) }\end{array}$ & 0.65 \\
\hline $\begin{array}{l}\text { NGAL } 12 \\
\text { hours after } \\
\text { kidney injury }\end{array}$ & $\begin{array}{c}297 \\
\text { (0 to } 385)\end{array}$ & $\begin{array}{c}400 \\
\text { (400 to } 400)\end{array}$ & $\begin{array}{c}400 \\
(400 \text { to } 400)\end{array}$ & $\begin{array}{c}400 \\
(400 \text { to } 400)\end{array}$ & $\begin{array}{c}400 \\
(400 \text { to } 400)\end{array}$ & 0.66 \\
\hline
\end{tabular}

\section{Discussion}

The important finding of the current investigation is the more severe kidney injury in rodents who received Hydroxyethyl starch infusion and underwent renal ischemia compared to rodents who received Ringer lactate. Rodents in the Hydroxyethyl starch group had a median $25-50 \%$ of renal tubular necrosis compared to $10-25 \%$ of tubular necrosis in rodents in the Ringer's lactate group. These findings can have important clinical implications since clinical practitioners often choose colloid solutions in hypoperfusion hemodynamic states in order to obtain a faster optimization of the intravascular volume. Colloid solutions may contribute to a more severe kidney injury than crystalloids in noninfectious hypoperfusion states of the kidney.

Another important finding of the current investigation is the lack of association between serum NGAL levels and the severity of kidney injury. This finding can have important clinical implications since the NGAL has been used as an early biomarker of nephrotoxicity in states of renal ischemia ${ }^{11,12}$. It is possible that by only measuring this serum biomarker of nephrotoxicity, important differences in the severity of kidney injury will not be detected. In contrast, Negishi et al. ${ }^{13}$ demonstrated that by monitoring a urinary L type fatty acid-binding protein the histological severity of acute kidney injury could be predicted. The urinary L type fatty acidbinding protein seems to be a better marker than the serum NGAL to evaluate severity of acute kidney injury.

Others have demonstrated the nephrotoxic effects of colloids in hypoperfusion states due to infectious causes. Schick et al. ${ }^{7}$ showed that a colloid infusion was associated with more renal dysfunction than crystalloid infusion in a model of rodent sepsis. The detrimental effects of colloids on the kidney in septic states was further confirmed in clinical patients. Brunkhorts et al. ${ }^{14}$ found that septic patients receiving $10 \%$ pentastarch developed more acute renal failure and needed more renal-replacement therapy than patients receiving Ringer's lactate. Based on our findings, it seems that colloids also exert nephrotoxicity in noninfections states of hypoperfusion. Confirmation of our findings in the clinical setting are therefore warranted.

Although not the objective of the current investigation, several mechanisms have been proposed to explain the nephrotoxic effects of colloids. Huter et al. ${ }^{15}$ demonstrated that hydroxyethylstarch (HES) induced osmotic nephrosis lesions using porcine kidneys in an isolated perfusion model over six hours. The effect of colloids in tubular cell damage is likely due to the pinocytosis of exogenous osmotic molecules analogous to what happens with iodinated contrasts ${ }^{16}$. We also observed pinocytotic tubular cell lesions in our investigation. It seems that colloids are detrimental to both glomerular and tubular components of renal function.

There are several limitations to the current study. First we did not use a sham group and could not compare the impact of crystalloid/colloid administration to the lack of fluid replacement 
therapy. Second, we did not measure postoperative glomerular function and were not able to evaluate the effect of our interventions on glomerular function. We also utilized a model that examined animals with a single kidney. A right nephrectomy was performed before the ischemic insult in order to allow a faster recovery of the ischemic left kidney as our group has demonstrated in a previous investigation ${ }^{17}$. If a right nephrectomy was not performed, the right kidney would cause a supra-physiologic activation of the reninangiotensin- aldosterone system which would lead to severe vasoconstriction and faster damage of the left kidney ${ }^{18}$.

\section{Conclusions}

The fluid replacement therapy with 6\% Hydroxyethyl starch lead to more kidney damage than fluid replacement therapy with Ringer' lactate in a non infectious renal ischemic model. Our results support previous findings of nephrotoxic damage of colloids in infectious states of hypoperfusion when compared to crystalloids. It seems that colloids should also be avoided to improve kidney function in non septic states of renal hypoperfusion.

\section{References}

1. Kheterpal S, Tremper KK, Englesbe MJ, O'Reilly M, Shanks AM, Fetterman DM, Rosenberg AL, Swartz RD. Predictors of postoperative acute renal failure after noncardiac surgery in patients with previously normal renal function. Anesthesiology. 2007;107:892-902.

2. Chertow GM, Burdick E, Honour M, Bonventre JV, Bates DW. Acute kidney injury, mortality, length of stay, and costs in hospitalized patients. J Am Soc Nephrol. 2005;16:3365-70.

3. Hashem R, Weissman C. Renal dysfunction and fluid and electrolyte disturbances. Curr Opin Crit Care. 2011;17:390-5.

4. Prowle JR, Bellomo R. Fluid administration and the kidney. Curr Opin Crit Care. 2010;16:332-6.

5. Roche AM, James MF. Colloids and crystalloids: does it matter to the kidney? Curr Opin Crit Care. 2009;15:520-4.

6. Perel P, Roberts I. Colloids versus crystalloids for fluid resuscitation in critically ill patients. Cochrane Database Syst Rev. 2011;16:CD000567.

7. Schick MA, Isbary TJ, Schlegel N, Brugger J, Waschke J, Muellenbach R, Roewer N, Wunder C. The impact of crystalloid and colloid infusion on the kidney in rodent sepsis. Intensive Care Med. 2010;36:541-8.

8. Vianna PT, Castiglia YM, Braz JR, Viero RM, Beier S, Vianna Filho PT, Vitória A, Reinoldes Bizarria Guilherme G, de Assis Golim M, Deffune E. Remifentanil, isoflurane, and preconditioning attenuate renal ischemia/reperfusion injury in rats. Transplant Proc. 2009;41:4080-2.

9. Silva AE, Castiglia YM, Módolo NS, Roberto WM, Braz LG, Vane LA, Vianna PT, Braz JR. Does the choice of the halogenated anesthetic influence renal function during hemorrhagic shock and resuscitation? Ren Fail. 2009;31:62-9.

10. Park Y, Hirose R, Dang K, Xu F, Behrends M, Tan V, Roberts JP, Niemann CU. Increased severity of renal ischemia-reperfusion injury with venous clamping compared to arterial clamping in a rat model. Surgery. 2008;143:243-51.

11. Mishra J, Dent C, Tarabishi R, Mitsnefes MM, Ma Q, Kelly C, Ruff SM, Zahedi K, Shao M, Bean J, Mori K, Barasch J, Devarajan P. Neutrophil gelatinase-associated lipocalin (NGAL) as a biomarker for acute renal injury after cardiac surgery. Lancet. 2005;365(9466):1231-8.

12. Smertka M, Chudek J. Using NGAL as an early diagnostic test of acute kidney injury. Ren Fail. 2012;34(1):130-3.

13. Negishi K, Noiri E, Doi K, Tanaka T, Hamasaki Y, Fujita T, Portilla D, Sugaya T. 6.Urinary fatty acid-binding protein 1: an early predictive biomarker of kidney injury. Am J Physiol Renal Physiol. 2009;296:F669-79.

14. Brunkhorst FM, Engel C, Bloos F, Meier-Hellmann A, Ragaller M, Weiler N, Moerer O, Gruendling M, Oppert M, Grond S, Olthoff D, Jaschinski U, John S, Rossaint R, Welte T, Schaefer M, Kern P, Kuhnt E, Kiehntopf M, Hartog C, Natanson C, Loeffler M, Reinhart $\mathrm{K}$.Intensive insulin therapy and pentastarch resuscitation in severe sepsis. N Engl J Med. 2008;358(2):125-39.

15. Hüter L, Simon TP, Weinmann L, Schuerholz T, Reinhart K, Wolf G, Amann KU, Marx G. Hydroxyethylstarch impairs renal function and induces interstitial proliferation, macrophage infiltration and tubular damage in an isolated renal perfusion model. Crit Care. 2009;13(1):R23.

16. Dickenmann M, Oettl T, Mihatsch MJ. Osmotic nephrosis: acute kidney injury with accumulation of proximal tubular lysosomes due to administration of exogenous solutes. Am J Kidney Dis. 2008;51:491-503.

17. Módolo NS, Castiglia YM, Ganem EM, Braz JR, Vianna PT, Vane LA. Acute renal ischemia model in dogs: effects of metoprolol. Ren Fail. 2001;23:1-10.

18. Fujii T, Takaoka M, Tsuruoka N, Kiso Y, Tanaka T, Matsumura Y. Dietary supplementation of L-carnosine prevents ischemia/ reperfusion-induced renal injury in rats. Biol Pharm Bull. 2005;28:361-3.

\section{Correspondence:}

Norma Sueli Pinheiro Módolo

Departmento de Anestesiologia

Faculdade de Medicina de Botucatú-UNESP

Rubião Júnior - Caixa Postal 530

18618-970 Botucatú - SP Brasil

Tel./Fax: (55 14)3811-6222

nmodolo@fmb.unesp.br

Received: August 20, 2012

Review: October 23, 2012

Accepted: November 21, 2012

Conflict of interest: none

Financial source: Sao Paulo Research Foundation (FAPESP) - Proc. 2010/08562-0

${ }^{1}$ Research performed at Experimental Laboratory, Department of Anesthesiology, Botucatu Medical School, State University of Sao Paulo (UNESP), Botucatu-SP, Brazil. Part of PhD degree thesis, Postgraduate Program in Anesthesiology. Tutor: Prof. Norma Sueli Pinheiro Módolo 